„Bohemistyka” 2021, nr 4, ISSN 1642-9893

\title{
Výuka bohemistiky
}

\section{na Filologické fakultě Lodžské univerzity opětovně zahájena}

Bohemistické vzdělávání v Polsku má již tradičně své nezastupitelné místo mezi filologickými obory, které aktuálně nabízejí a úspěšně rozvíjejí již osvědčené lektoráty na univerzitách ve Varšavě, v Krakově, Poznani a v Katovicích. Informace o zř́ízení nového lektorátu českého jazyka a literatury na Lodžské univerzitě může být mnohými vnímána jako přirozené pokračování populárního studijního oboru a zároveň i výzva pro všechny zájemce o studium bohemistiky v tomto polském regionu.

\section{Otevření lektorátu českého jazyka a literatury na Lodžské univerzitě}

Lektorát českého jazyka a literatury byl zřizen na Filologické fakultě Lodžské univerzity teprve v roce 2019. Slavnostní imatrikulace studentů 1. ročníku bohemistiky a otevření lektorátu českého jazyka a literatury dne 4. prosince roku 2019 se zúčastnili velvyslanec České republiky v Polsku Ivan Jestřáb, honorární konzul České republiky v Lodži Krzysztof Skotnicki, rektor Lodžské univerzity Antoni Różalski, děkanka Filologické fakulty Lodžské univerzity Joanna Jabłkowska, vedoucí katedry slovanské filologie Ivan N. Petrov, studenti a vyučující z katedry slovanské filologie.

Program imatrikulace byl koncipován v duchu připomínky již uplynulého třicátého výročí od začátku sametové revoluce v Československu. Po úvodních proslovech př́tomných hostů následovalo promítnutí působivé prezentace o listopadových událostech roku 1989 v Československu doprovázené známou písní Modlitba pro Martu interpretky Marty Kubišové. Poté vybraní studenti předčítali stř́idavě v českém a polském jazyce ukázky z Hrabalovy knihy Dopisy Dubence. Po oficiální části imatrikulace následovala integrační zábavná vzdělávací lekce pro všechny studenty češtiny, srbštiny, bulharštiny a slovinštiny. Studenti a lektoři si připravili pro př́tomné zábavné kvízy o ceny, vtipné prezentace, chutné minutky a tradiční krajová jídla. Součástí integračního setkání byla vědomostní soutěž mladých slavistů Lodžské univerzity. 


\section{Organizace bohemistických studií, personální a materiální zabezpečení}

\section{lodžského lektorátu}

Katedra slovanské filologie nabízí vzdělání v oboru slovanské filologie na dvou úrovních vzdělání (trŕleté bakalářské a dvouleté magisterské studium).

Polští studenti mohou od akademického roku 2019/20 na Lodžské univerzitě studovat češtinu v rámci programu Filologie, ve specializaci Slovanská filologie a zvolit si k ní jeden z jihoslovanských jazyků - bulharštinu nebo srbštinu. Během studia prvního ročníku studenti získají znalosti a jazykové kompetence z jednoho jazyka na úrovni B1, z druhého jazyka na úrovni A2 (podle Společného evropského referenčního rámce).

Filologicky orientovaná výuka je zaměřena na získání dovedností z oblasti lingvistiky, kulturních reálií, písemného projevu a plynulé komunikace v sociální interakci. Bakalářský studijní program nabízí výběr specializací: cestovní ruch (přednášejí vyučující z Fakulty geografických věd Lodžské univerzity) a dvou cizích jazyků. Dosažené kompetence a dovednosti pak může absolvent uplatnit $v$ praxi v různých oblastech profesního a společenského života (například v cestovním ruchu, v kulturních institucích, ve státní správě a všude tam, kde je požadována znalost jihoslovanských jazyků a kultur) anebo může pokračovat v navazujícím studiu v magisterském studijním programu. Studenti lodžské slavistiky kromě studia, lze uvést i učení se dvěma vybraným jazykům, získavají znalosti z historie, kultury a literatury slovanských národů. Poznavají také duchovní i lidovou kulturu Slovanů a geopolitickou situaci Balkánu. Při Katedře slovanské filologie působí vědecký Kruh slavistů svatých Cyrila a Metoděje.

\section{Vědecká činnost}

Zaměstnanci katedry slovanské filologie na univerzitě v Lodži provádějí výzkum slovanských jazyků a literatur a realizují vědecké projekty. Výzkum zahrnuje lingvistiku (komparativní lingvistiku slovanských jazyků včetně analýzy překladů, studie moderních bulharských, srbských a slovinských jazyků, dějiny slovanských jazyků, slovanskou paleografii), literární vědu (církevní slovanskou literaturu se zvláštním důrazem na starou bulharskou literaturu, současnou slovanskou literaturu), kulturu (lidovou a duchovní kulturu Slovanů) a glotodidaktiku. Katedra slovanské filologi produkuje překlady literárních textů z různých období, díla zahraničních vědců a také vydává vědecké časopisy a ediční řady. Zaměstnanci katedry spolupracují s mnoha výzkumnými centry v Polsku i v zahraničí.

\section{Literatur}

B y č k o v J., 2021, Představuje se nový lektorát, „Krajiny češtiny” [v tisku].

Łódź. Online: https://en.wikipedia.org/wiki/Łódź [cit. 21.03.2021] 